\title{
Morphological and germination physiognomies of Carissa carandas seedlings influenced by seed storage at ambient conditions
}

\author{
Deepika $^{* 1}$ and K. Vanajalatha ${ }^{2}$ \\ ${ }^{* 1}$ Department of Fruit science, Dr Yashwant Singh Parmar University of Horticulture and Forestry, Solan \\ -173230 (Himachal Pradesh), INDIA \\ ${ }^{2}$ Deparmtent of Fruit Science, Sri Konda Laxman Telangana State Horticultural University, Hyderbad-500030, \\ INDIA \\ *Corresponding author. E-mail:deepi.mystery@gmail.com
}

Received: December 2, 2016; Revised received: April 17, 2017; Accepted: August 28, 2017

\begin{abstract}
The present study was taken up to know the morphological and germination physiognomies of karonda (Carissa carandas) seeds influenced by seed storage period at ambient conditions $\left(26{ }^{\circ} \mathrm{C}\right.$ temperature and $55 \%$ $\mathrm{RH})$. Seeds were subjected to store at $10,20,30,40,50$ and 60 days at room temperature $\left(26^{\circ} \mathrm{C}\right)$. Germination percentage and various morphological characteristics viz., vigour index, fresh weight of shoot and root, dry weight of shoot and root, root to shoot ratio were recorded. Among stored seeds 10 days old seeds recorded highest germination percentage $(57 \%)$ and 60 days old seeds recorded lowest germination $(20.33 \%)$. At the end (90 days after sowing) 10 days old seeds again possessed higher fresh weight of root $(0.300 \mathrm{~g})$ and shoot $(1.240 \mathrm{~g})$, dry weight of root $(0.103 \mathrm{~g})$ and shoot $(0.487 \mathrm{~g})$, root to shoot ratio $(0.212)$ and vigour index $(1772.70 \mathrm{~cm})$ among stored seeds. These physiological observations were quite similar with the freshly harvested seed which found maximum values for all the parameters owing to higher moisture content. Karonda seeds showed good viability upto10 days thereafter its value declined and it reached minimum after 60 days of storage.
\end{abstract}

Keywords: Germination, Stored Seed, Root to Shoot Ratio, Vigour Index, Karonda

\section{INTRODUCTION}

Seed viability under storage conditions is known to vary from species to species and depends on many factors (temperature, moisture content etc.). Seeds of some fruit crops are known lose viability during storage at room temperature $\left(20-25^{\circ} \mathrm{C}\right)$ or in the cold room $\left(7-10^{\circ} \mathrm{C}\right)$ (Prins and Maghembe 1994). During storage seed deterioration occurs. Several environmental factors contribute to seed deterioration and these conditions make very difficult to maintain viability during storage. However, the seed quality and viability during storage also depends upon the initial quality of seed and the manner in which it is stored. Seed deterioration is associated with various cellular (broken plasmalemma structure, contraction of plasmalemma from cell wall, fragmented endoplasmic reticulum and organelles devoid of poly-ribosomes), metabolic and chemical alterations including lipid peroxidation, membrane disruption, DNA damage, impairment of RNA and protein synthesis and cause several detrimental effects on seed (Jyoti \& Malik, 2013, Umarani et al., 2015 and Sun et al., 2007). Proper functioning of the cell organelles is a prerequisite for longer seed viability period. This low seed viability contributes to the poor seed germination of many wild fruit tree species, such that it is difficult to obtain sufficient propagules (Akinnifesi et al., 2007).

Carissa carandas Linn. (Family - Apocynaceae) is an important medicinal perennial species is native to India and distributed in Sri Lanka, Indonesia, Malaysia, Myanmar and Pakistan (Hegde et al., 2009). It is an evergreen thorny shrub and produces sub acidic fruit rich in vitamin $\mathrm{C}$ and minerals. Fruits contain protein, carbohydrate, fat, minerals, fibre and calcium, phosphorus, iron. C. carandas have astringent properties, fruit is used to expel intestinal worms, it has anti-microbial and antifungal properties, fruits are also used as analgesic and anti-inflammatory. The juice of fruit can be applied to relieve any skin problem. Traditionally karonda has been used to treat anorexia and insanity (Rahmatullah et al., 2009 and Mall \& Tripathi, 2017). Owing to its hardy nature with wide adaptability it has excellent potential to be used for horticultural plantations in marginal and wastelands (Bankar et al., 1994). Conventionally, $C$. carandas is propagated through seeds, cuttings, grafting, air layering, and stooling (Misra \& Jaiswal, 1993 and Tyagi et al., 1999). However, these methods are season-specific and require a long time to propagate. As seeds are important starting materials for propagation of many fruit crops. The use of seeds as propagules has been considered the easiest and cheapest, and the most common means for many fruit crops (Akinnifesi et al., 2007). Generally, this has 
been attributed to the fact that seeds are often easy to produce and handle (Black, 1989). Comparatively, vegetative propagation methods such as grafting, budding and air layering require some skills and knowledge.

Scientific propagation is the basis for expansion of area under perennial crops. The propagation techniques help for conservation of plants besides multiplication. Seeds of karonda have short viability and should be sown just after extraction from fruits (Kumar et al., 2007). According to Mngomba et al (2007) perennial plant species flower and fruit once in a year and also the seeds lose their viability quickly. Loss of seed quality, viability and vigour is seed deterioration (Kapoor et al., 2010). Deterioration is evident as a reduction in percentage germination, produce weak seedlings, loss of vigour, become less viable and ultimately seed death (Tilebeni and Golpayegani, 2011). Consequently, seed longevity is necessary through which the quality planting materials can be made available throughout the year. Before providing the conditions for reducing seed deterioration during storage, information on relative storability of seeds of particular fruit crops under ambient conditions is required. Very limited work is done in this crop thus this study was conducted with the objective of studying the morphological and germination physiognomies of Carissa carandas seedlings influenced by seed storage at ambient conditions.

\section{MATERIALS AND METHODS}

The experiment was performed at Agricultural Research Institute, Rajendranagar, Hyderabad during 2012 which comprised of seven treatments with three replication and under each replications hundred seeds were taken. Treatments included freshly extracted seed, 10 days stored seed, 20 days stored seed, 30 days stored seed, 40 days stored seed, 50 days stored seed and 60 days stored seed.

Seeds were removed from the ripe fruits of plants by soaking in water for overnight and were separated by rubbing the seeds against hard surface. The seeds were then washed with water to remove the mucilaginous covering over the seed surface and were shade dried for one day except for the first treatment where freshly harvested seeds were taken for sowing. Further, the seeds were kept in butter paper bags and stored at room temperature $\left(26{ }^{\circ} \mathrm{C}\right.$ temperature and $\left.55 \% \mathrm{RH}\right)$ for ten, twenty, thirty, forty, fifty and sixty days. These stored seeds (different days old seeds) after soaking in water were sown for seed germination studies. Seeds were sown in poly bags of $15 \times 22 \mathrm{~cm}$ size, previously filled with potting mixture (Red soil, FYM and Soil in equal parts). The bags were watered regularly at 24 hours interval and prophylactic plant protection measures were taken up to control the pests and diseases. The following observations viz., Germination per- centage (\%), Fresh weight of root and shoot (g), Dry weight of root and shoot $(\mathrm{g})$, Root to Shoot ratio and Vigour index in terms of seedling length using the following formula $(\mathrm{cm})$ were taken at 30, 60 and 90 days after sowing.

Vigour index $(\mathrm{cm})=$ Mean seedling length $\mathrm{X}$ per cent germination.

$$
\text { Root : Shoot ratio }=\frac{\text { Dry weight of the root }(\mathrm{g})}{\text { Dry weight of the shoot }(\mathrm{g})}
$$

Statistical analysis of the data on various parameters was done by following the (ANOVA) as given by Panse and Shkhatme (1989).

\section{RESULTS AND DISCUSSION}

Germination percentage (\%): Data presented in Table 1 revealed that after 90 days of sowing the highest germination was noticed in freshly extracted seed $\left(\mathrm{T}_{1}\right)$ $(66.67 \%)$ followed by $\mathrm{T}_{2}(57 \%), \mathrm{T}_{3}(44.33 \%), \mathrm{T}_{4}$ $(36.67 \%), \mathrm{T}_{5}(30.33 \%), \mathrm{T}_{6}(25.67 \%)$. Germination percentage reached minimum values of 20 per cent after 60 days of seed storage i.e. $T_{7}$. Thus the data on germination percentage indicated the loss of viability with advanced seed storage period at ambient conditions $\left(26^{\circ} \mathrm{C}\right.$ temperature). This might be due to various reasons suggested by various workers one of reason being decrease in seed moisture content during storage of seeds. High moisture content in freshly extracted seeds might cause higher germination. Another explanation for this sharp decline in seed viability at 60 days of storage could be the accelerated progression of seed deterioration in the surrounding environment resulting in loss their vigour and become more susceptible to environmental stresses during germination and finally are not able to germinate (Mbofung et al., 2013). Seed deterioration is associated with various cellular, metabolic and chemical alterations including chromosome aberrations and damage to the DNA, impairment of RNA and protein synthesis, changes in the enzymes and food reserves and loss of membrane integrity (Kibinza et al., 2006). Present results are also in accordance with Mallareddy et al. (1977) who studied on changes in germinability of citrus seeds during storage and reported that in mandarin and grape fruit, the germination of all fresh seeds ranged from 77 to $84 \%$. After storage for 80 days the germination lowered in grapefruit (12-40\%) and mandarin (9-24\%). Gowda et al. (2011) observed that the tamarind seeds were viable upto 270 days with $43 \%$ germination, jackfruit seeds viable upto 150 days with $20 \%$ germination and jamun (Syzygium cuminii) seeds viable upto 150 days with $30 \%$ germination. Tilebeni and Golpayegani (2011) and Mbofung et al. (2013) also stated decreased germination rate coefficient of soybean and rice seeds by increasing storage duration.

Fresh weight of root and Shoot (g): Data on fresh weight of root and fresh weight of shoot is indicated in 
Table 1. Effect of storage duration on Germination, Fresh weight of root, Fresh weight of shoot and Vigou index of Karonda seedlings.

\begin{tabular}{|c|c|c|c|c|c|c|c|c|c|c|}
\hline \multirow{3}{*}{ Treatments } & \multirow{3}{*}{$\begin{array}{l}\text { Germination } \\
\text { percentage } \\
(\%)\end{array}$} & \multicolumn{3}{|c|}{ Fresh weight of root (g) } & \multicolumn{3}{|c|}{ Fresh weight of shoot (g) } & \multicolumn{3}{|c|}{ Vigou index (cm) } \\
\hline & & \multicolumn{3}{|c|}{ Days after sowing } & \multicolumn{3}{|c|}{ Days after sowing } & \multicolumn{3}{|c|}{ Days after sowing } \\
\hline & & 30 & 60 & 90 & 30 & 60 & 90 & & & 90 \\
\hline $\mathrm{T}_{1}$ - Freshly & 66.67 & 0.040 & 0.123 & 0.333 & 0.147 & 0.580 & 1.533 & 734.67 & 1378.00 & 2110.67 \\
\hline $\begin{array}{l}\text { extracted } \\
\text { seed }\end{array}$ & & & & & & & & & & \\
\hline $\begin{array}{l}\mathrm{T}_{2}-10 \text { days } \\
\text { stored seed }\end{array}$ & 57.00 & 0.040 & 0.113 & 0.300 & 0.140 & 0.573 & 1.240 & 609.33 & 1125.75 & 1772.70 \\
\hline $\begin{array}{l}\mathrm{T}_{3}-20 \text { days } \\
\text { stored seed }\end{array}$ & 44.33 & 0.027 & 0.097 & 0.233 & 0.123 & 0.453 & 0.727 & 442.89 & 829.48 & 1293.65 \\
\hline $\begin{array}{l}\mathrm{T}_{4}-30 \text { days } \\
\text { stored seed }\end{array}$ & 36.67 & 0.023 & 0.087 & 0.223 & 0.117 & 0.293 & 0.633 & 362.63 & 677.23 & 1022.27 \\
\hline $\begin{array}{l}\mathrm{T}_{5}-40 \text { days } \\
\text { stored seed }\end{array}$ & 30.33 & 0.023 & 0.067 & 0.153 & 0.110 & 0.260 & 0.563 & 272.09 & 533.26 & 831.44 \\
\hline $\begin{array}{l}\mathrm{T}_{6}-50 \text { days } \\
\text { stored seed }\end{array}$ & 25.67 & 0.023 & 0.060 & 0.120 & 0.103 & 0.233 & 0.510 & 226.89 & 430.17 & 681.67 \\
\hline $\begin{array}{l}\mathrm{T}_{7}-60 \text { days } \\
\text { stored seed }\end{array}$ & 20.33 & 0.013 & 0.057 & 0.113 & 0.097 & 0.207 & 0.477 & 167.55 & 324.93 & 521.35 \\
\hline Mean & 40.14 & 0.027 & 0.086 & 0.211 & 0.119 & 0.371 & 0.811 & 402.29 & 756.97 & 1176.25 \\
\hline $\mathrm{SEm} \pm$ & 0.49 & 0.002 & 0.004 & 0.011 & 0.006 & 0.013 & 0.064 & 5.10 & 9.50 & 14.99 \\
\hline $\mathrm{CD} @ 5 \%$ & 1.54 & 0.006 & 0.013 & 0.033 & 0.019 & 0.041 & 0.196 & 15.88 & 29.59 & 46.71 \\
\hline
\end{tabular}

Table 2. Effect of storage duration on Dry weight of root, Dry weight of shoot and Root to shoot ratio of Karonda seedlings.

\begin{tabular}{|c|c|c|c|c|c|c|c|c|c|}
\hline \multirow{3}{*}{ Treatments } & \multicolumn{3}{|c|}{ Dry weight of root (g) } & \multicolumn{3}{|c|}{ Dry weight of shoot (g) } & \multicolumn{3}{|c|}{ Root to shoot ratio } \\
\hline & \multicolumn{3}{|c|}{ Days after sowing } & \multicolumn{3}{|c|}{ Days after sowing } & \multicolumn{3}{|c|}{ Days after sowing } \\
\hline & 30 & 60 & 90 & 30 & 60 & 90 & 30 & 60 & 90 \\
\hline $\begin{array}{l}\mathrm{T}_{1} \text { - Freshly extracted } \\
\text { seed }\end{array}$ & 0.013 & 0.046 & 0.120 & 0.029 & 0.133 & 0.538 & 0.464 & 0.340 & 0.225 \\
\hline $\mathrm{T}_{2}-10$ days stored seed & 0.012 & 0.033 & 0.103 & 0.028 & 0.113 & 0.487 & 0.439 & 0.309 & 0.212 \\
\hline $\mathrm{T}_{3}-20$ days stored seed & 0.010 & 0.026 & 0.077 & 0.026 & 0.091 & 0.378 & 0.378 & 0.277 & 0.207 \\
\hline $\mathrm{T}_{4}-30$ days stored seed & 0.009 & 0.022 & 0.070 & 0.026 & 0.080 & 0.347 & 0.340 & 0.273 & 0.200 \\
\hline $\mathrm{T}_{5}-40$ days stored seed & 0.007 & 0.019 & 0.055 & 0.023 & 0.074 & 0.298 & 0.317 & 0.260 & 0.190 \\
\hline $\mathrm{T}_{6}-50$ days stored seed & 0.006 & 0.019 & 0.049 & 0.020 & 0.071 & 0.264 & 0.294 & 0.257 & 0.187 \\
\hline $\mathrm{T}_{7}-60$ days stored seed & 0.005 & 0.016 & 0.045 & 0.018 & 0.067 & 0.253 & 0.283 & 0.247 & 0.177 \\
\hline Mean & 0.009 & 0.025 & 0.074 & 0.024 & 0.089 & 0.366 & 0.359 & 0.280 & 0.199 \\
\hline $\mathrm{SEm} \pm$ & 0.001 & 0.001 & 0.004 & 0.001 & 0.004 & 0.016 & 0.024 & 0.009 & 0.006 \\
\hline CD @ $5 \%$ & 0.003 & 0.004 & 0.012 & 0.004 & 0.012 & 0.049 & 0.075 & 0.028 & 0.020 \\
\hline
\end{tabular}

Table 1 and statistically significant at 5 per cent level. 90 days after sowing (DAS), minimum fresh weight of roots was recorded in $T_{7}$ (60 days old seed) $(0.113 \mathrm{~g})$, whereas $\mathrm{T}_{3}$ (20 days old seed) $(0.233 \mathrm{~g})$ and $\mathrm{T}_{4}(30$ days old seed) $(0.223 \mathrm{~g})$ were at par with each other and recorded more fresh weight of root than $\mathrm{T}_{5}(0.153$ g) and $T_{6}(0.120 \mathrm{~g})$. Fresh seeds $\left(\mathrm{T}_{1}\right)$ showed maximum fresh weight of root $(0.333 \mathrm{~g})$ which was quite close with $\mathrm{T}_{2}(0.300 \mathrm{~g})$. Among the treatments fresh weight of shoot was lowest in $\mathrm{T}_{7}(0.477 \mathrm{~g})$ and highest was in $\mathrm{T}_{1}(1.533 \mathrm{~g})$ followed by $\mathrm{T}_{2}(1.240 \mathrm{~g})$. The observations from Table 1 confirms a trend of decrease in fresh weight of root and shoot with advanced period of seed storage. Declined vigour in terms of fresh weight of seedling might be attributed to the phenomenon of seed deterioration and decreased mobilization of reserve substances during germination of the stored seeds. During seed deterioration, membrane degradation increase high level of electrolyte leakage leads to decline in seedling vigour. Alterations of membrane systems, such as the tonoplast, plasmalemma and endoplasmic reticulum, result in diminishing of normal cell function and energy production thereby reduce seedling vigour (Malik and Jyoti, 2013). Also plants that have originated from deteriorated seed can also reduce growth rate (Kapoor et al., 2010). Similar results were found by Gayathri (2001), Dias et al. (2010) and Tatic et al. (2012). Present finding is also in line with Vanitha et al., (2005) in cocoa. According to authors, initial seed moisture content on the first day $(35.46 \%)$ got reduced after nine days of seed storage $(12 \%)$ with a concomitant reduction in viability (12 $\%)$, root length $(6.32 \mathrm{~cm})$ and shoot length $(22.40 \mathrm{~cm})$. In jamun (Syzygium cuminii) fruits highest root length $(8.2 \mathrm{~cm})$ and shoot length $(17.8 \mathrm{~cm})$ were obtained with water wash after one day fermentation (Srimathi et al., 2003). The storage is one of the important factors affecting the seed quality. At immediate seed ex- 
traction, the vigour in terms of fresh weight basis was generally highest in the crop, but during storage it changes. Seed vigour is the first component of seed quality that decreases and consequently the germination potential will also reduce during storage (Sheidaei et al., 2014).

Dry weight of root and shoot (g): Maximum dry weight of root is recorded in freshly extracted seeds i.e. $\mathrm{T}_{1}(0.120 \mathrm{~g})$ and minimum was observed in $\mathrm{T}_{7}$ $(0.045 \mathrm{~g}) . \mathrm{T}_{2}(0.103 \mathrm{~g})$ recorded more dry weight of root than $\mathrm{T}_{3}(0.077 \mathrm{~g})$ and $\mathrm{T}_{4}(0.070 \mathrm{~g})$ which were at par with each other and superior than $\mathrm{T}_{5}(0.055 \mathrm{~g})$ and $\mathrm{T}_{6}(0.049 \mathrm{~g})$. Seeds sown immediately after removal from fruit $\left(\mathrm{T}_{1}\right)$ found higher dry weight of shoot $(0.538$ g) followed by $\mathrm{T}_{2}(0.0487 \mathrm{~g})$. The lowest value of dry weight of shoot was in 60 days stored seed $\left(\mathrm{T}_{7}\right)(0.253$ g) which was at par with $\mathrm{T}_{5}$ and $\mathrm{T}_{6}(0.298 \mathrm{~g}$ and 0.264 $\mathrm{g}$ respectively). Fresh seeds showed maximum dry weight of root $(0.120 \mathrm{~g})$ and shoot $(0.538 \mathrm{~g})$ and a trend of decline in dry weight of root and shoot was noticed as the period of seed storage increased. This may be attributed to aging of seeds during storage. The oxidative deterioration of polyunsaturated lipids in cellular membrane leading free radical chain reaction is considered to be the primary reason of aging (ISTA, 1985). Poor membrane structure and leaky cells are usually associated with deterioration and low vigour seeds. According to Yalleshkumar et al. (2007) in Mango, Four and six days old stones found to be most efficient in increasing primary root length and production of secondary roots $(19.51 \mathrm{~cm}$ and 14.44 number of roots respectively). Dry weight of root and shoot was highest in four days after extraction (18.63 $\mathrm{g}$ and 7.19 g) and lowest in 16 days after extraction (13.55 and $4.97 \mathrm{~g}$ respectively). Our results were also in close conformity with the findings of Vanitha et al., (2005) in cocoa, where reduction in dry matter production (118 mg) and vigour index (339) after nine days of seed storage was observed which was $232 \mathrm{mg}$ and 2877 respectively on first day after seed storage and also vaibility potential reached zero after 10 days. Similar reports were obtained by Gayathri (2001) in asparagus and tomato.

Root to shoot ratio: Data pertaining to root to shoot ratio is depicted in Table 2. Significant difference (at 5 $\%$ level of significance) was found between different treatments. It was observed that Root to Shoot was influenced by period of seed storage and 90 days after sowing its value reached minimum in $\mathrm{T}_{7}(0.177)$ which was at par with $\mathrm{T}_{6}(0.187)$. Highest root shoot ratio was noticed in $T_{1}(0.225)$ which was at par with $T_{2}$ $(0.212)$ and $T_{3}(0.207)$. Quite close values in root to shoot ratio of fresh seeds, ten days and twenty days old seeds indicated that ten day and twenty days old seeds had maintained proper root to shoot ratio thereafter it declined. This decline might be because of more vigour of fresh seeds, 10 and 20 days old seeds. Aged seeds showed decreased root to shoot ratio as reported by Eisvand et al. (2010) in Broomgrass seeds.

Vigour index (cm): Data concerning to vigour index (cm) is presented in Table 1. It revealed that freshly extracted seed i.e. $\mathrm{T}_{1}$ recorded maximum vigour index (2110.67) followed by seeds sown after 10 days stored seed i.e. $\mathrm{T}_{2}(1772.70)$, which was minimum in 60 days stored seed i.e. $\mathrm{T}_{7}$ (521.35). The vigour index value declined as the storage period prolonged. Makkawi and Gastel (2006) also reported a reduction in seedling dry mass after different periods of ageing on seeds of different varieties of lentil (Lens culinaris Medikus). The loss of vigour and viability in aged seed might be associated with enhanced lipid peroxidation and depressed metabolic system to limit the damage from free radical and peroxide as reported by Sung (1996) in soyabean. The free radical induces non enzymatic peroxidation has the potential to damage membranes, enzymes and nucleic acids, and likely to be one of the major causes of deterioration of stored seed (Wilson and McDonald, 1986), hence resulted in loss in vigour. Singh and Singh (1981) reported that the duration of storage (4 months to 20 months) and condition of storage (room and cold conditions) for storing papaya seeds influence the vigour of the seedlings. With the increase in the duration of storage from 4 months to 20 months shoot length $(8.5 \mathrm{~cm}$ to $3.33 \mathrm{~cm})$ and dry weight of seedlings (155.60 $\mathrm{mg}$ to $47.13 \mathrm{mg}$ ) decreased under room temperature. Present results are also in agreement with number of research workers in different fruit crops. Declined seedling vigour with increased period of seed storage in Rangpur lime was also observed by Venkat (2004).

\section{Conclusion}

These results permitted to conclude that the karonda seeds lost their germination capacity with increasing storage time with a very low germination and seedling vigour after 60 days of storage at ambient conditions, while 10 days stored seed maintained good seedling vigour and other growth parameters. Planting material of karonda is highly demanded in the experimental area; therefore the seeds could be stored upto 10 days without much decline in seedling vigour to meet the farmers requirement. Furthermore, more research work is warranted to enhance germplasm multiplication programs and proper storage conditions of karonda seeds to improve germination physiognomies.

\section{REFERENCES}

Akinnifesi, F.K., Sileshi, G., Mkonda, A., Ajayi, O.C., Mhango, J. and Chilanga, T. (2007). Germplasm supply, propagation and nursery management of Miombofruit trees. Indigenous Fruit Trees in the Tropics: Domestication, Utilization andCommercialization, CABI publishing, UK in press.

Bankar, G.J., Verma, S.K. and Prasad, R.N.(1994). Fruit for arid region: Karonda. Indian Horticulture.39: 46- 47. 
Black, M. (1989). Seed research - past, present and future. In: Taylorson RB (Ed)Recent Advances in the Development and Germination of Seeds. Series A,Life Sciences Vol 187, Plenum Press, NY, 295 pp.

Dias, S.D.F.C.D., Estanislau, T.W., Finger, L.F., Alvarenga, M.E. and Dias, S.D.A.L. (2010). Physiological and enzymatic alterations in papaya seed during storage. Revista Brasileira de Sementes.32(1): 148-157.

Eisvand, H.R., Alizadeh, M.A. and Fekri, A. (2010). How hormonal priming of aged and nonaged seeds of Bromegrass affects seedling physiological characters. Journal of New Seeds. 11: 52-64.

Gayathri, M. (2001). Studies on seed invigoration to promote seed germination and seedling development in hybrid tomato seeds. M.Sc. (Agri.) Thesis, Uni. Agric. Sci. Bangalore, Karnataka.

Gowda, V.N., Smitha, M.N. and Reddy, P.V.K. (2011). Studies on seed viability, germination and seedling growth of minor fruit plants. Acta Horticulture. 890: 135-138.

Hegde, K., Thakker, S.P., Joshi, A.B., Shastry, C.S. and Chandrashekhar, K.S. (2009). Anticonvulsant Activity of Carissa carandas Linn. Root Extract in Experimental Mice. Tropical Journal of Pharmaceutical Research. 8 (2): 117-125

ISTA. (1985). International rules for seed testing. Seed Science and Technology. 13: 299-355.

Jyoti and Malik, C.P. (2013). Seed deterioration: a review. International journal of life sciences biotechnology and pharma research. 2 (3): 374-385.

Kapoor, N., Arya, A., Siddiqui, M.A., Amir, A. and Kumar, H. (2010). Seed deterioration in chickpea (Cicer arietinum L.) under accelerated aging. Asian journal of Plant Science. 9: 158-162.

Kibinza, S., Vinel, D., Come, D., Bailly, C. and Corbineau, F. (2006). Sunflower seed deterioration as related to moisture content during ageing, energy metabolism and active oxygen species scavenging. Physiologia Plantarum. 128(3): 496-506.

Kumar, D., Pandey, V. and Nath, V. (2007). Karonda (Carissa congesta) an underutilized fruit crop. In: Peter, K.V. (eds), Underutilized and underexploited Horticultural Crops. New India publishing agency. 1: 313-325.

Makkawi, M. and Gastel, A.J.G. (2006). Effect of accelerated ageing on germination and vigour of lentil (Lens culinaris Medikus) seed. Journal of New Seeds. 8:87-97.

Mall, T. P. and Tripathi, S.C. (2017). Diversity of Wild Nutrimental Fruits of District Bahraich, Uttar Pradesh, India. International Journal of Current Research in Biosciences and Plant Biology. 4(1): 65-76.

Mallareddy, K., Sharma, B.B. and Singh, R. (1977). Changes in germinability of citrus seeds during storage. Seed Research. 5(2): 145-151.

Mbofung, G.C.Y., Goggi, A.S., Leandro, L.F.S. and Mullen, R.E. (2013). Effects of storage temperature and relative humidity on viability and vigour of treated soybean seeds. Crop Science. 53:1086-1095.

Misra, K.K. and Jaiswal, H.R. (1993). A study on the effect of indolbutyric acid on rooting of stool layers of karonda (Carissa carandas L.). Annals of Agricultural Research. 14(2): 235-236.

Mngomba, S.A., Toit, E.S., Akinnifesi, F.K. and Venter,
H.M. (2007). Effective preconditioning methods for in vitro propagation of Uapaca kirkiana Müell Arg. tree species. African Journal of Biotechnology. 6: 16701676.

Panse, V.G. and Sukhatme. (1989). Statistical methods for agricultural workers, ICAR Pub. New Delhi.

Prins, H., Maghembe, J.A. (1994). Germination studies on seed of fruit trees indigenous to Malawi. Forest Ecology and Management. 64: 111-125.

Rahmatullah, M., Mollik, M.A.H., Azam, A.T.M.A., Islam, M.R., Chowdhury, M.A.M., Jahan, R., Chowdhury, M.H. and Rahman, T. (2009). Ethnobotanical survey of the Santal tribe residing in Thakurgaon District, Bangladesh. American Eurasian Journal of Sustainable Agriculture. 3: 889-898.

Sheidaei, S., Abad, H.H.S., Hamidi, A., Mohammadi, G.N., Moghaddam, A. (2014). Evaluation of soybean seed quality under long term storage. International Journal of Biosciences. 5(3): 214-219.

Singh, R.M. and Singh, I.D. (1981). Effect of method and duration of storage on seed germination and seedling vigour in papaya (Carica papaya L.). Seed Research. 9 (1): $67-72$.

Srimathi, P., Ramanadane, T., Malarkodi, K. and Natarajan, K. (2003). Seed extraction in Jamun (Syzygium cuminii Skeels). Progressive Horticulture. 35(2): 221-223.

Sun, Q., Wang, J. and Sun, B. (2007). Advances on seed vigor physiology and genetic mechanisms. Agriculture Science China. 6:1060-1066.

Sung, J.M. (1996). Lipid peroxidation and peroxide scavenging in soyabean seeds during ageing. Physiologia plantarum. 97: 85-89.

Tatic, M., Tubic, S.B., Dordevic, V., Nikolic, Z., Dukic, V., Vujakovic, M. and Cvijanovic, G. (2012).Soybean seed viability and changes of fatty acids content as affected by seed aging.African Journal of Biotechnology.11(45): 10310-10316.

Tilebeni, G. and Golpayegani, A. (2011). Effect of seed ageing on physiological and biochemical changes in rice seed (Oryza sativa L.). International Journal of AgriScience. 1(3): 138-143.

Tyagi, S., Misra, K.K. and Jaiswal, H.R. (1999). Effect of rooting of softwood stem cuttings of carrisa under mist. Scientific Horticulture. 6:37-43.

Umarani, R., Kanthaiya, E., Aadhavan and Faisal, M.M. (2015). Understanding poor storage potential of recalcitrant seeds. Current Science. 108 (11): 2023-2034

Vanitha, C., Ramamurthi, K., Vijykumar, A. and Sivasubramaniam, K. (2005). Moist sand conditioning to minimize loss of viability in cocoa (Theobroma cacao linn.) seed. Natural Product Radiance.4(6): 487-491.

Venkat.(2004). Exploitation of rangpur lime as a rootstock for different citrus sp.Msc (Hort.) Thesis, Univ. Agric.Sci. Dharwad.

Wilson, D.O. and Mc-Donald, M.B. (1986). The lipid peroxidation model of seed deterioration. Seed Science and Technology. 14: 269-300.

Yalleshkumar, H.S., Swamy, G.S.K., Kanamadi, V.C., Patil, C.P., Kumar, P. and Athani, S.I. (2007). Studies on viability of mango stones and its effect on germination and rootstock vigour. Journal of Asian Horticulture. 3 (3): 205-207. 